\title{
Model Matematika SEIR Pada Kanker Kulit Akibat Paparan Sinar Ultraviolet Di Provinsi Sulawesi Selatan
}

\author{
Syafruddin Side ${ }^{1}$, Ahmad Zaki ${ }^{1}$, dan Norliana Rahmasari ${ }^{1, \text { a) }}$ \\ ${ }^{1}$ Jurusan Matematika, Fakultas Matematika dan Ilmu Pengetahuan Alam \\ Universities Negeri Makassar \\ a)norliana98rahmasari@gmail.com
}

\begin{abstract}
Abstrak. Penelitian ini bertujuan untuk membangun model matematika SEIR pada kanker kulit akibat paparan sinar ultraviolet dengan asumsi bahwa terdapat masa inkubasi pada kanker kulit. Model ini dibagi menjadi 4 kelas yaitu susceptible, exposed, infected dan recovered. Adapun prosedur penelitian dilakukan melalui tahapan-tahapan: membuat model SEIR pada kanker kulit di provinsi Sulawesi Selatan, menentukan titik ekuilibrium model, analisis kestabilan titik ekuilibrium, menentukan bilangan reproduksi dasar $\left(R_{0}\right)$. Data yang digunakan dalam membangun model adalah penderita kanker kulit tahun 2018 hingga tahun 2019 dari Rumah Sakit Wahidin Sudirohusodo kota Makassar. Hasil yang diperoleh bahwa semakin besar persentase laju kesembuhan tiap individu yang terinfeksi karena adanya pengobatan mengakibatkan populasi pada kelas recovered semakin meningkat dan populasi pada kelas infected mengalami penurunan. Dengan kata lain penyakit kanker kulit tidak mewabah di Provinsi Sulawesi Selatan.
\end{abstract}

Kata Kunci: Titik Equilibrium, Bilangan Reproduksi Dasar, Kanker Kulit, Model SEIR

\begin{abstract}
This study aims to build a mathematical model of SEIR in skin cancer due to ultraviolet light exposure assuming that there is an incubation period in skin cancer. This model is divided into 4 classes namely susceptible, exposed, infected and recovered. The research procedure is carried out through the stages: make a SEIR model on skin cancer in the province of South Sulawesi, determine the equilibrium point of the model, analyze the stability of the equilibrium point, determine the base reproduction number $\left(R_{0}\right)$. The data used in building the model were skin cancer sufferers from 2018 to 2019 from Sudirohusodo Wahidin Hospital in Makassar. The results obtained that the greater the percentage of recovery rate of each infected individual due to treatment causes the population of the recovered class to increase and the population of the infected class to decrease. In other words skin cancer is not endemic in South Sulawesi Province.
\end{abstract}

Keywords: Equilibrium Point, Basic Reproductive Numbers, Skin Cancer, SEIR Model

\section{PENDAHULUAN}

Hubungan antara komponen-komponen dalam suatu masalah yang dirumuskan dalam suatu persamaan matematik yang memuat komponen-komponen itu sebagai variabelnya, dinamakan model matematika. Proses untuk memperoleh model dari suatu masalah disebut pemodelan matematika. Kegunaan yang dapat diperoleh dari model matematika ini antara lain : 1) Menambah kecepatan, kejelasan dan kekuatan gagasan dalam waktu yang relatif singkat; 2) Deskripsi masalah menjadi pusat perhatian; 3) Mendapatkan pengertian atau kejelasan mekanisme dalam 
masalah; 4) Dapat digunakan untuk memprediksi kejadian yang akan muncul dari suatu fenomena; 5) Sebagai dasar perencanaan dan kontrol dalam pembuatan kebijakan, dan lain-lain (Side \& Rangkuti, 2015). Model matematika banyak digunakan dalam berbagai disiplin ilmu, salah satunya ilmu kesehatan. Pada bidang kesehatan, model matematika digunakan untuk mengetahui bagaimana penyebaran suatu penyakit menular maupun tidak menular dan jumlah penderita suatu penyakit baik yang berupa epidemik maupun tidak (Hanisar, 2016).

Pada model epidemi SEIR populasi dibagi menjadi empat kelompok yaitu suspek dengan simbol $\mathrm{S}$, ekspose dengan simbol E, terinfeksi dengan simbol I dan sembuh dengan simbol R, yang masing - masing diberikan dalam bentuk SEIR. S atau Susceptable merupakan idividu yang tidak terinfeksi tetapi golongan ini dapat tertular penyakit, E atau Exposed merupakan individu yang menunjukkan gejala infeksi, I atau Infected merupakan individu yang terinfeksi penyakit dan dapat sembuh dari penyakit. $\mathrm{R}$ atau recovered merupakan individu yang telah sembuh dari penyakit (Iswanto, 2012).

Salah satu fenomena penyebaran penyakit yang dapat dimodelkan dalam bentuk matematika yaitu tentang kanker kulit. Kanker merupakan penyakit yang dicirikan dengan pertumbuhan sel yang tidak terkontrol dan penyebaran sel abnormal. Kanker disebabkan oleh faktor eksternal, seperti: merokok, terinfeksi oleh virus atau bakteri, serta gaya hidup yang tidak sehat; dan faktor internal, seperti: mewarisi gen yang termutasi, hormon, serta kondisi imun tubuh (Rosidah, Sardjono, \& Sumardi, 2017).

Kanker kulit secara umum diklasifikasikan menjadi dua kelompok yaitu melanoma skin cancer (MSC) dan non-melanoma skin cancer (NMSC). Melanoma merupakan kanker paling sering kelima yang didiagnosis di Amerika Serikat, dengan insiden 21,9 per 100.000 ribu pasien per tahun. Insiden yang rendah di populasi Asia dengan kejadian 0,2 - 0,5 kasus per 100.000 pasien per tahun (Kim \& Yun, 2016). Jenis kanker kulit yang paling banyak terjadi di Indonesia adalah BCC (65,5\%), SCC (23\%), melanoma maligna (7,9\%), dan jenis lainnya (Wilvestra, Lestari \& Asri, 2018). Di sulawesi selatan insiden penderita kanker kulit berjumlah 121 kasus atau 2,1\% dengan jumlah kematian 8 orang (Fadillah, 2017).

Beberapa peneliti yang telah mengkaji terkait penyakit kanker kulit dan model SEIR pada penyakit diantaranya adalah Hendaria, Asmarajaya, \& Maliawan (2013) mengkaji tentang kanker kulit. Svobodova, Walterova, \& Vostalova (2006) mengkaji tentang Perubahan ultraviolet yang di induksi terhadap kulit. Side dan Rangkuti (2015) mengkaji tentang Pemodelan Matematika dan Solusi Numerik untuk Penularan Demam Berdarah. Side (2015) mengkaji tentang Model SEIR pada Penularan Hepatitis B. Maka pada penelitian ini akan mengkombinasikan penelitian tersebut dengan judul "Model Matematika SEIR Pada Kanker Kulit akibat Paparan Sinar Ultraviolet di Provinsi Sulawesi Selatan".

Tujuan dari penelitian ini untuk mengetahui model matematika SEIR pada kanker kulit akibat paparan sinar ultraviolet, mengetahui kestabilan model kanker kulit akibat paparan sinar ultraviolet, mengetahui hasil simulasi model SEIR pada kanker kulit akibat paparan sinar ultraviolet menggunakan software Maple.

\section{KAJIAN PUSTAKA}

\section{Persamaan Diferensial}

Persamaan diferensial adalah persamaan yang meliputi turunan fungsi dari satu atau lebih variabel terikat terhadap variabel bebas. Berdasarkan turunan fungsi terhadap variabel bebas, persamaan diferensial dibagi menjadi dua yaitu persamaan diferensial biasa dan persamaan diferensial parsial (Campbell \& Haberman, 2008). 


\section{Titik Tetap}

Misal diberikan sistem persamaan diferensial sebagai berikut :

$$
\frac{d x}{d t}=f(x, y), \quad \frac{d y}{d t}=g(x, y)
$$

Dengan $\mathrm{f}$ dan $\mathrm{g}$ merupakan fungsi kontinu dari $\mathrm{x}$ dan $\mathrm{y}$, serta derivatif parsial pertamanya juga kontinu.Titik kritis sistem (1) adalah titik $\bar{x}=(x, y)$ sedemikian sehingga $\mathrm{f}(\bar{x})=\mathrm{g}(\bar{x})=0$. Titik kritis $\bar{x}$ merupakan solusi dari sistem persamaan diferensial (1) yang bernilai konstan, sebab $\frac{d x}{d t}=$ 0 dan $\frac{d y}{d t}=0$. Keadaan yang menyebabkan $\frac{d x}{d t}=0$ dan $\frac{d y}{d t}=0$ disebut keadaan setimbang, sehingga titik kritis tersebut juga titik kesetimbangan (Edward dan Penney, 2001). Titik kesetimbangan disebut juga titik stasioner (tetap) atau suatu posisi yang mantap (steady state) dari variabel, maka $\bar{x}=(x, y)$ adalah titik kesetimbangan (Robinson, 2004).

\section{Jenis - Jenis Kestabilan}

Sifat dan jenis kestabilan hampir seluruhnya bergantung pada akar-akar karakteristik (Hariyanto, 1992). Menurut Ross (1984) Misal diberikan sistem tak linear

Di mana :

$$
\begin{aligned}
& \frac{d x}{d t}=a x+b y+f_{1}(x, y) \\
& \frac{d y}{d t}=c x+d y+g_{1}(x, y)
\end{aligned}
$$

1. $a, b, c$ dan $d$ konstan real dan $\left|\begin{array}{ll}a & b \\ c & d\end{array}\right| \neq 0$

2. $f_{1}(x, y)$ dan $g_{1}(x, y)$ mempunya derivative parsial kontinu untuk semua $(x, y)$ dan memenuhi

$$
\lim _{(x, y) \rightarrow(0,0)} \frac{f_{1}(x, y)}{\sqrt{x^{2}+y^{2}}}=\lim _{(x, y) \rightarrow(0,0)} \frac{g_{1}(x, y)}{\sqrt{x^{2}+y^{2}}}=0
$$

Bentuk sistem liniernya dari sistem persamaan (1) berbentuk $\frac{d x}{d t}=a x+b y$ dan $\frac{d y}{d t}=c x+d y$. Kedua sistem mempunyai titik kritis di $(0,0)$. Misalkan $\lambda_{1}$ dan $\lambda_{2}$ akar-akar dari persamaan karakteristik berbentuk

$$
\lambda^{2}-(a+d) \lambda+(a d-b c)=0
$$

Bentuk akar-akar dari persamaan tersebut merupakan sistem linier. Untuk menentukan stabilitasmaka titik kritis $(0,0)$ dari sistem linier maupun sistem non linier dapat ditinjau dari ketentuan-ketentuarn sebagai berikut:

1. Jika kedua akar persamaan karakteristik dari sistem linier adalah real, negatif atau kompleks sekawan dengan bagian real negatif maka titik kritis $(0,0)$ menpakan titik kritis stabil asimtotik dari sistem linier maupun sistem non linier.

2. Jika akar-akar persamaan karakteristik imajiner murni maka titik kritis $(0,0)$ adalah titik kritis stabil pada sistem linier tetapi bukan titik kritis stabil pada sistem non linier. Titik kritis $(0,0)$ pada sistem tak linier dapat berbentuk stabil asimtotik, stabil tetapi tidak asimtot, atau tidak stabil.

3. Jika salah satu atau kedua akar dari persamaan karakteristik adalah real dan positif atau berupa akar-akar kompleks sekawan dengan bagian real positif maka titik kritis $(0,0)$ menupalan titik kritis tidak stabil pada sistem linier maupun sistem non linier (Ross, 1984). 


\section{Bilangan Reproduksi Dasar}

Bilangan reproduksi dasar merupakan bilangan yang menunjukkan jumlah individu rentan yang dapat menderita penyakit yang disebabkan oleh satu individu terinfeksi. Bilangan reproduksi dasar dilambangkan dengan $R_{0}$ dengan beberapa kondisi yang akan timbul, yaitu :

1. Jika $R_{0}<1$, maka penyakit akan menghilang.

2. Jika $R_{0}=1$, maka penyakit akan menetap.

3. Jika $R_{0}>1$, maka penyakit akan meningkat menjadi wabah.

\section{Kanker Kulit}

Kanker kulit adalah suatu penyakit yang disebabkan oleh berubahnya sifat-sifat penyusun sel kulit yang normal menjadi ganas, dimana sel-sel akan terus membelah menjadi bentuk yang abnormal secara tidak terkontrol akibat kerusakan DNA. Bila dilihat dari segi histopatologik memiliki struktur yang tidak teratur dengan diferensiasi sel dalam berbagai tingkatan pada kromatin, nukleus, dan sitoplasma (Hendaria, dkk, 2013).

\section{METODE PENELITIAN}

Jenis penelitian yang digunakan adalah studi literatur dan terapan. Adapun literatur yang digunakan terdiri dari buku dan artikel yang dimuat pada jurnal yang berkaitan dengan persamaan diferensial dan kanker kulit. Yang menjadi objek dari penelitian ini adalah penderita kanker kulit pada tahun 2018 hingga tahun 2019 dengan tidak memperhatikan jenis kelamin dan umur.

Tahapan yang akan dilakukan dalam penelitian berdasarkan rumusan masalah adalah:

1. Tahapan untuk membuat model SEIR terhadap kanker kulit di provinsi Sulawesi Selatan

a. Mengumpulkan informasi tentang kanker kulit di provinsi Sulawesi Selatan.

b. Menentukan asumsi dan mendefinisikan parameter yang digunakan pada model SEIR.

c. Memformulasikan model SEIR pada kanker kulit berdasarkan batasan, asumsi, dan parameter yang telah dibuat.

2. Tahapan untuk analisis model SEIR terhadap kanker kulit di provinsi Sulawesi Selatan

a. Menentukan titik ekuilibrium model berdasarkan persamaan yang telah diperoleh.

b. Analisis kestabilan titik ekuilibrium.

c. Menentukan bilangan reproduksi dasar $\left(R_{0}\right)$.

3. Tahapan untuk simulasi model SEIR terhadap kanker kulit di provinsi Sulawesi Selatan menggunakan software Maple18.

a. Menentukan nilai awal yang diperoleh dari data penderita kanker kulit di provinsi Sulawesi Selatan.

b. Menginput model ke dalam software Maple18.

c. Menginput nilai-nilai parameter yang digunakan dalam model.

d. Menginterpretasikan hasil simulasi.

e. Menarik kesimpulan dari hasil simulasi model SEIR.

\section{HASIL PENELITIAN}

\section{Formulasi Model}

Model SEIR pada kanker kulit dibagi menjadi empat kelas, yaitu Kelas Susceptible (S) menyatakan kelas yang rentan terhadap kanker kulit, kelas Exposed (E) menyatakan kelas yang menunjukkan gejala kanker kulit, kelas infected (I) menyatakan kelas yang terinfeksi dan kelas 
Recovered (R) menyatakan kelas yang membaik/sembuh dari kanker kulit. Diperlukan beberapa asumsi dalam membentuk model. Adapun asumsi-asumsi yang digunakan adalah sebagai berikut.

a. Populasi penduduk bersifat tertutup dengan artian bahwa pertambahan ataupun pengurangan jumlah penduduk melalui emigrasi dan imigrasi tidak diperhatikan.

b. Hanya terdapat satu penyakit yang menyebar dalam populasi.

c. Laju kelahiran dan laju kematian diasumsikan sama. Setiap individu yang lahir masuk kedalam kelas individu Susceptible dan setiap individu yang mati dari setiap kelas mempunyai laju proporsional dengan jumlah individu pada masing-masing kelas.

d. Terdapat masa inkubasi (periode laten) pada proses pembentukan kanker kulit.

e. Individu yang berada dalam periode laten tidak dapat menularkan penyakit.

f. Individu yang terinfeksi kanker kulit dapat sembuh.

Berikut ini didefinisikan variabel dan parameter yang digunakan dalam model disajikan dalam Tabel 1.

TABEL 1. Variabel dan Parameter yang Digunakan Dalam Model

\begin{tabular}{cl}
\hline Simbol & \multicolumn{1}{c}{ Definisi } \\
\hline$S$ & Jumlah individu rentan terhadap kanker kulit \\
& Jumlah individu yang mengalami gejala namun belum \\
$I$ & terinfeksi \\
$R$ & Jumlah individu terinfeksi kanker kulit \\
$\mu_{1}$ & Jumlah individu yang sembuh dari kanker kulit \\
$\mu_{2}$ & $\begin{array}{l}\text { Laju kelahiran } \\
\text { Laju individu rentan menjadi individu laten karena terpapar } \\
\beta\end{array}$ \\
& sinar ultraviolet \\
& Laju individu yang terinfeksi kanker kulit \\
& Laju kesembuhan tiap individu yang terinfeksi karena \\
& adanya pengobatan
\end{tabular}

skema model matematika SEIR pada kanker kulit yang dapat dilihat pada Gambar 1.

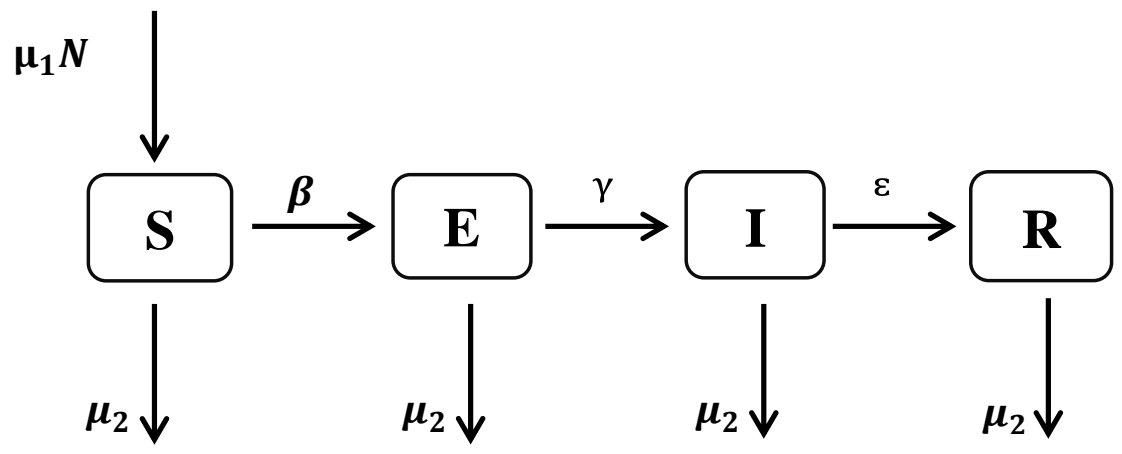

GAMBAR 1. Skema Model Matematika SEIR pada Kanker Kulit Akibat Paparan Sinar Ultraviolet 
Berdasarkan asumsi dan hubungan antara parameter pada Gambar 1 dapat dijelaskan pada persamaan berikut :

$$
\begin{aligned}
& \frac{d S}{d t}=\mu_{1} N-\mu_{2} S-\beta S \\
& \frac{d E}{d t}=\beta S-\mu_{2} E-\gamma E \\
& \frac{d I}{d t}=\gamma E-\mu_{2} I-\varepsilon I \\
& \frac{d R}{d t}=\varepsilon I-\mu_{2} R
\end{aligned}
$$

Dengan $N(t)=S(t)+E(t)+I(t)+R(t)$

Untuk menyederhanakan sistem (2), dapat digunakan penskalaan, yaitu membentuk sistem (2) menjadi bentuk proporsi antara banyaknya individu dalam suatu subpopulasi dengan banyaknya populasi total. Kemudian untuk menyederhanakan notasi, dimisalkan

$$
s=\frac{S}{N}, e=\frac{E}{N}, i=\frac{I}{N}, r=\frac{R}{N}
$$

sehingga sistem (2) dapat disederhanakan seperti berikut.

$$
\begin{aligned}
& \frac{d s}{d t}=\mu_{1}-\mu_{2} s-\beta s \\
& \frac{d e}{d t}=\beta s-\mu_{2} e-\gamma e \\
& \frac{d i}{d t}=\gamma e-\mu_{2} i-\varepsilon i \\
& \frac{d r}{d t}=\varepsilon i-\mu_{2} r
\end{aligned}
$$

dengan $s(t)+e(t)+i(t)+r(t)=1$

\section{Analisis Model dan Analisis Kestabilan}

Titik $(s, e, i, r)$ merupakan titik-titik ekuilibrium dari sistem (3) jika memenuhi persamaan $\frac{d s}{d t}, \frac{d e}{d t}, \frac{d i}{d t}, \frac{d r}{d t}=0$. Terdapat dua titik ekuilibrium pada sistem (3), yaitu titik ekuilibrium bebas penyakit dan titik ekuilibrium endemik. Untuk mengetahui titik ekuilibrium bebas penyakit, diasumsikan $e=0$ dan $i=0$ yang berarti bahwa tidak ada individu yang terinfeksi dan tidak ada pula penanganan yang diberikan. Berdasarkan sistem (3) titik ekuilibrium bebas penyakit adalah $E_{0}=(s, e, i, r)=\left(\frac{\mu_{1}}{\mu_{2}}, 0,0,0\right)$.

Untuk mengetahui titik ekuilibrium endemik, misalkan $E_{\varepsilon}\left(s^{*}, e^{*}, i^{*}, r^{*}\right)$ maka diasumsikan $s^{*}, e^{*}, i^{*}, r^{*} \neq 0$. Sehingga diperoleh titik ekuilibrium endemik adalah $E_{\varepsilon}=\left(s^{*}, e^{*}, i^{*}, r^{*}\right)=$ $\left(\frac{\mu_{1}}{\mu_{2}+\beta}, \frac{\beta \mu_{1}}{\left(\mu_{2}+\beta\right)\left(\mu_{2}+\gamma\right)}, \frac{\gamma \beta \mu_{1}}{\left(\mu_{2}+\beta\right)\left(\mu_{2}+\gamma\right)\left(\mu_{2}+\varepsilon\right)}, \frac{\varepsilon \gamma \beta \mu_{1}}{\left(\mu_{2}+\beta\right)\left(\mu_{2}+\gamma\right)\left(\mu_{2}+\varepsilon\right) \mu_{2}}\right)$.

\section{Penentuan jenis kestabilan titik ekuilibrium}

Jenis kestabilan titik ekuilibrium bebas penyakit $E_{0}$ diperoleh dengan melakukan pelinearan pada sistem persamaan (4) disekitar $E_{0}$, sehingga diperoleh matriks Jacobian sebagai berikut.

$$
J\left(E_{0}\right)=\left[\begin{array}{cccr}
-\mu_{2}-\beta & 0 & 0 & 0 \\
\beta & -\mu_{2}-\gamma & 0 & 0 \\
0 & \gamma & -\mu_{2}-\varepsilon & 0 \\
0 & 0 & \varepsilon & -\mu_{2}
\end{array}\right]
$$


Untuk mengetahui kestabilan $E_{0}$, maka dicari nilai eigen dari matiks $J\left(E_{0}\right)$ dengan menentukan $\operatorname{det}\left(J\left(E_{0}\right)-\lambda \mathrm{I}\right)=0$ dimana $\lambda$ adalah nilai eigen dan I adalah matriks identitas.

$\operatorname{det}\left(J\left(E_{0}\right)-\lambda \mathrm{I}\right)=0$

$\operatorname{det}\left(\left[\begin{array}{cccc}-\mu_{2}-\beta & 0 & 0 & 0 \\ \beta & -\mu_{2}-\gamma-\lambda & 0 & 0 \\ 0 & \gamma & -\mu_{2}-\varepsilon-\lambda & 0 \\ 0 & 0 & \varepsilon & -\mu_{2}\end{array}\right]-\lambda\left[\begin{array}{llll}1 & 0 & 0 & 0 \\ 0 & 1 & 0 & 0 \\ 0 & 0 & 1 & 0 \\ 0 & 0 & 0 & 1\end{array}\right]\right)=0$

$\operatorname{det}\left(\left[\begin{array}{cccc}-\mu_{2}-\beta-\lambda & 0 & 0 & 0 \\ \beta & -\mu_{2}-\gamma-\lambda & 0 & 0 \\ 0 & \gamma & -\mu_{2}-\varepsilon-\lambda & 0 \\ 0 & 0 & \varepsilon & -\mu_{2}-\lambda\end{array}\right]\right)=0$

diperoleh nilai eigen yaitu $\lambda_{1}, \lambda_{2}, \lambda_{3}, \lambda_{4}$ dengan $\lambda_{1}=-\mu_{2}-\beta, \lambda_{2}=-\mu_{2}-\gamma, \lambda_{3}=-\mu_{2}-\varepsilon$, $\lambda_{4}=-\mu_{2}$. Karena $\mu_{2}, \beta, \gamma, \varepsilon$ bernilai positif maka bagian real dari keempat nilai eigen tersebut adalah negatif sehingga titik ekuilibrium bebas penyakit $E_{0}$ bersifat stabil. Keempat nilai eigen tersebut adalah negatif sehingga titik ekuilibrium bebas penyakit $E_{0}$ bersifat stabil.

Selanjutnya menentukan jenis kestabilan titik ekuilibrium endemik $E_{\varepsilon}$ dengan cara yang sama seperti menentukan jenis kestabilan titik ekuilibrium bebas penyakit $E_{0}$. Sehingga diperoleh nilai eigen yaitu $\lambda_{1}=-\mu_{2}-\beta, \lambda_{2}=-\mu_{2}-\gamma, \lambda_{3}=-\mu_{2}-\varepsilon, \lambda_{4}=-\mu_{2}$. Karena $\mu_{2}, \beta, \gamma, \varepsilon$ bernilai positif maka bagian real dari keempat nilai eigen tersebut adalah negatif sehingga titik ekuilibrium endemik $E_{\varepsilon}$ bersifat stabil.

\section{Bilangan reproduksi dasar}

Bilangan reproduksi dasar diperoleh dengan menentukan nilai eigen dari matriks Jacobian dari suatu sistem persamaan (model) yang dihitung pada titik ekuilibrium bebas kecanduan. Perhatikan persamaan (5) berikut.

$$
\left(-\mu_{2}-\beta-\lambda\right)\left(-\mu_{2}-\gamma-\lambda\right)\left(-\mu_{2}-\varepsilon-\lambda\right)\left(-\mu_{2}-\lambda\right)=0
$$

Nilai reproduksi dasar dari persamaan (4) diperoleh dari bagian konstannya sehingga diperoleh $R_{0}=\mu_{2} \varepsilon \beta \gamma+(\beta \gamma+\beta \varepsilon+\gamma \varepsilon) \mu_{2}^{2}+(\beta+\gamma+\varepsilon) \mu_{2}^{3}+\mu_{2}^{4}$

\section{Simulasi Model}

Simulasi dilakukan menggunakan software. Diberikan nilai awal yang disajikan pada TABEL 2.

TABEL 2. Nilai Awal

\begin{tabular}{ccl}
\hline Variable & Nilai & \multicolumn{1}{c}{ Sumber } \\
\hline $\mathrm{N}$ & 8819500 & $\begin{array}{l}\text { Badan Pusat Statistik } \\
\text { Sulawesi Selatan }\end{array}$ \\
$S$ & 8818990 & $\begin{array}{l}\text { Rumah Sakit Wahidin } \\
\text { Sudirohusodo }\end{array}$ \\
$E$ & 193 & $\begin{array}{l}\text { Rumah Sakit Wahidin } \\
\text { Sudirohusodo } \\
\text { Rumah Sakit Wahidin } \\
\text { Sudirohusodo } \\
\text { Rumah Sakit Wahidin } \\
\text { Sudirohusodo }\end{array}$ \\
\hline
\end{tabular}


Parameter-parameter yang digunakan dalam model ini dapat dilihat pada TABEL 3 sebagai berikut:

TABEL 3. Parameter Model SEIR pada Kanker Kulit

\begin{tabular}{cccc}
\hline Variable & Nilai Parameter 1 & Nilai Parameter 2 & Nilai Parameter 3 \\
\hline$\mu_{1}$ & 0,083 & 0,083 & 0,083 \\
$\mu_{2}$ & 0,083 & 0,083 & 0,083 \\
$\beta$ & 0,000022 & 0,000022 & 0,000022 \\
$\gamma$ & 0,97 & 0,97 & 0,97 \\
$\varepsilon$ & 0,1 & 0,5 & 0,9 \\
\hline
\end{tabular}

Parameter yang telah diperoleh tersebut kemudian dimasukkan ke persamaan (4), sehingga didapatkan formulasi model SEIR untuk kasus kanker kulit di Provinsi Sulawesi Selatan pada tahun 2018 sampai dengan 2019 sebagai berikut:

$$
\begin{aligned}
& \frac{d s}{d t}=0.083-0.083 s-0.000022 s \\
& \frac{d e}{d t}=0.000022 s-0.083 e-0.97 e \\
& \frac{d i}{d t}=0.97 e-0.083 i-\varepsilon i \\
& \frac{d r}{d t}=\varepsilon i-0.083 r
\end{aligned}
$$

Model kanker kulit memiliki nilai bilangan reproduksi dasar $\left(R_{0}\right)$ yaitu :

$$
\begin{array}{cr}
R_{0}=\mu_{2} \varepsilon \beta \gamma+(\beta \gamma+\beta \varepsilon+\gamma \varepsilon) \mu_{2}^{2}+(\beta+\gamma+\varepsilon) \mu_{2}^{3}+\mu_{2}^{4} \\
\text { Parameter 1 } & R_{0}=0.001327855279 \\
\text { Parameter 2 } & R_{0}=0.004230271191 \\
\text { Parameter 3 } & R_{0}=0.007132687102
\end{array}
$$

Nilai $R_{0}<1$, berarti seseorang yang terinfeksi tidak menyebabkan orang lain terkena penyakit yang sama, dengan kata lain tidak terjadi wabah pada populasi tersebut. Karena nilai bilangan reproduksi dasar $\left(R_{0}\right)$ yang diperoleh lebih kecil dari satu, ini menunjukkan penyakit kanker kulit di Sulawesi Selatan tidak mengalami peningkatan dan tidak mewabah.

Simulasi untuk $\varepsilon=0,1$ dimana parameter $\varepsilon$ adalah laju kesembuhan tiap individu yang terinfeksi karena adanya pengobatan.

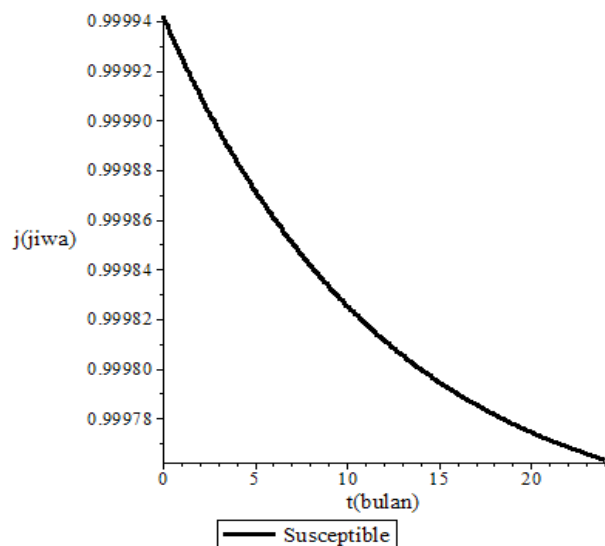

(a)

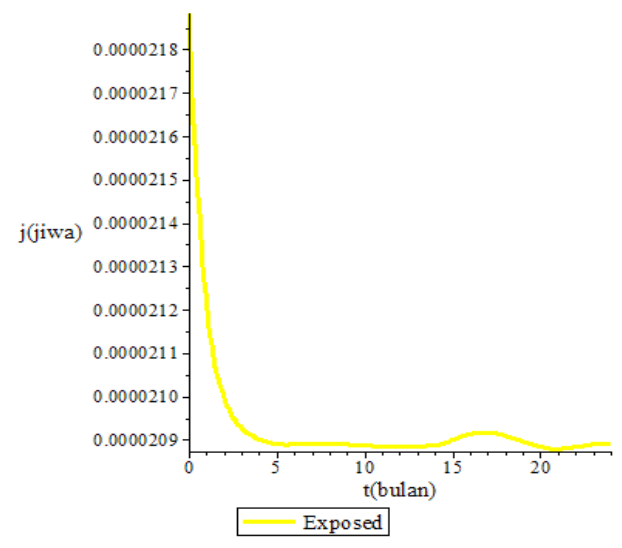

(b)

GAMBAR 2. (a) Simulasi untuk populasi susceptible

(b) Simulasi untuk populasi exposed 
Gambar 2(a) dapat dilihat bahwa populasi individu rentan (susceptible) mengalami penurunan dari di titik awal 8.818.970 jiwa pada bulan ke-0 dan menghilang pada bulan ke-24.

Gambar 2(b) dapat dilihat bahwa populasi individu yang menunjukkan gejala (exposed) mengalami penurunan dari titik awal 193 menuju 191 jiwa di bulan ke-14 selanjutnya populasi mengalami naik turun hingga bulan ke-24.

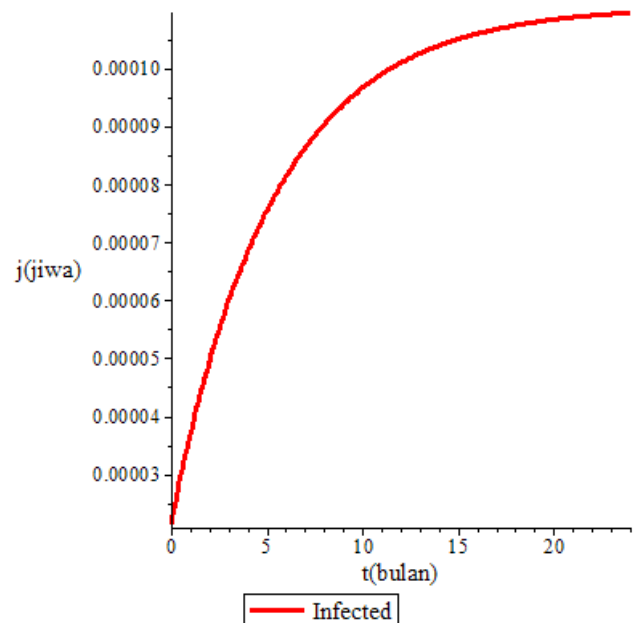

(c)

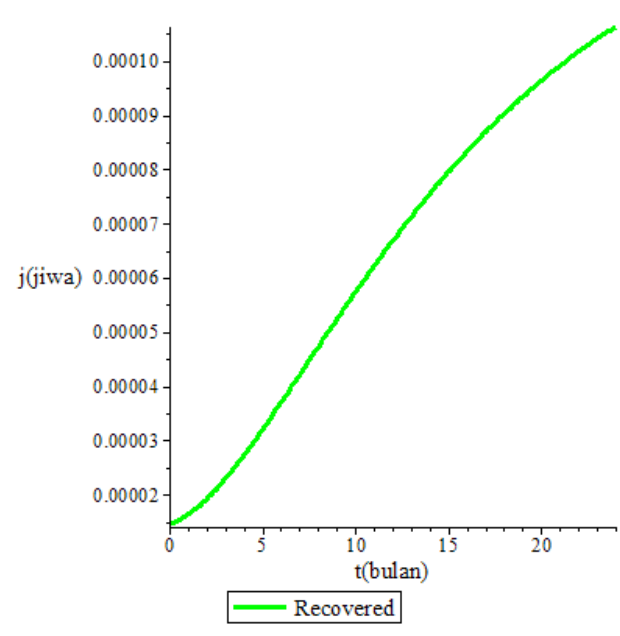

(d)

GAMBAR 2. (c) Simulasi untuk populasi infected

(d) Simulasi untuk populasi recovered

Gambar 2(c) dapat dilihat bahwa populasi individu yang terinfeksi (infected) mengalami peningkatan secara drastis dari bulan ke-0 hingga bulan ke-24 dengan jumlah populasi 1323 jiwa.

Gambar 2(d) dapat dilihat bahwa populasi individu yang sembuh (recovered) mengalami peningkatan secara drastis dari bulan ke-0 hingga bulan ke-24 yaitu dari titik awal 88 menuju 970 jiwa.

Simulasi untuk $\varepsilon=0,5$ dimana parameter $\varepsilon$ adalah laju kesembuhan tiap individu yang terinfeksi karena adanya pengobatan.

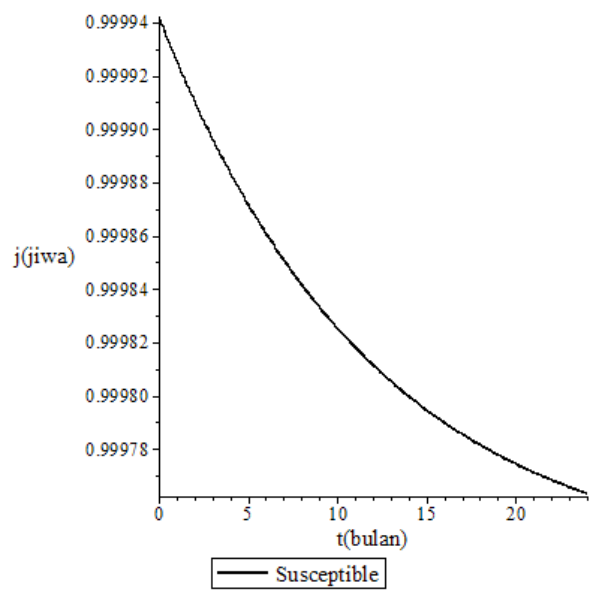

(a)

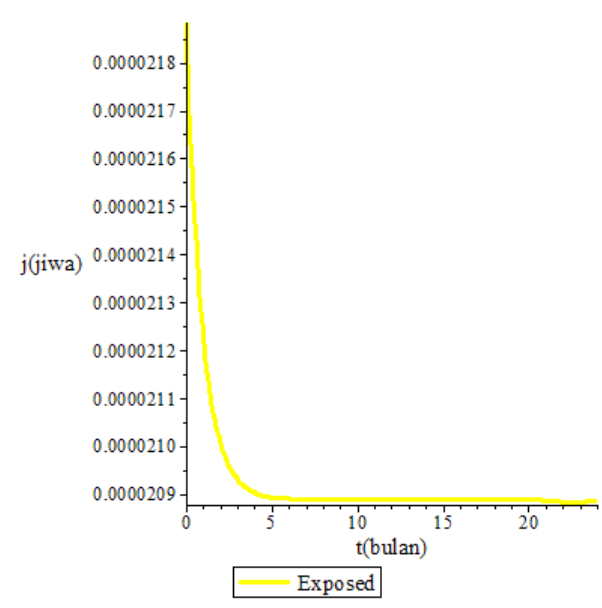

(b)

GAMBAR 3. (a) Simulasi untuk populasi susceptible

(b) Simulasi untuk populasi exposed 
Gambar 3(a) dapat dilihat bahwa populasi individu rentan (susceptible) mengalami penurunan di titik awal 8.818.970 jiwa pada bulan ke-0 dan menghilang pada bulan ke-24.

Gambar 3(b) dapat dilihat bahwa populasi individu yang menunjukkan gejala (exposed) mengalami penurunan dari titik awal 193 jiwa di bulan ke-0 hingga menghilang pada bulan ke24.

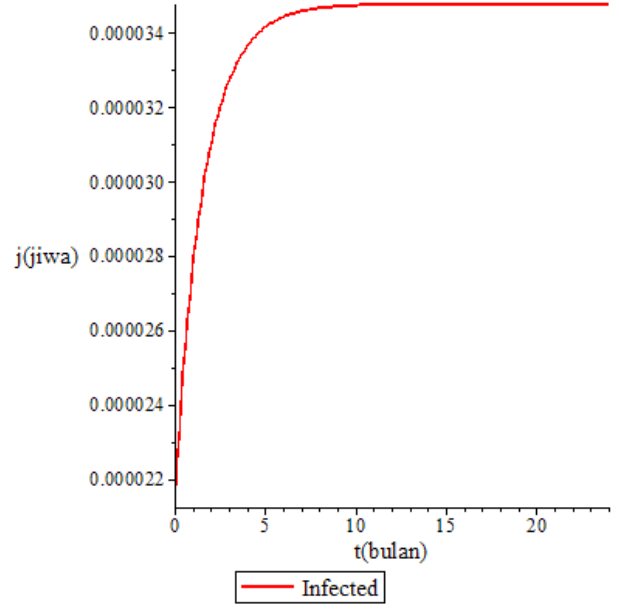

(c)

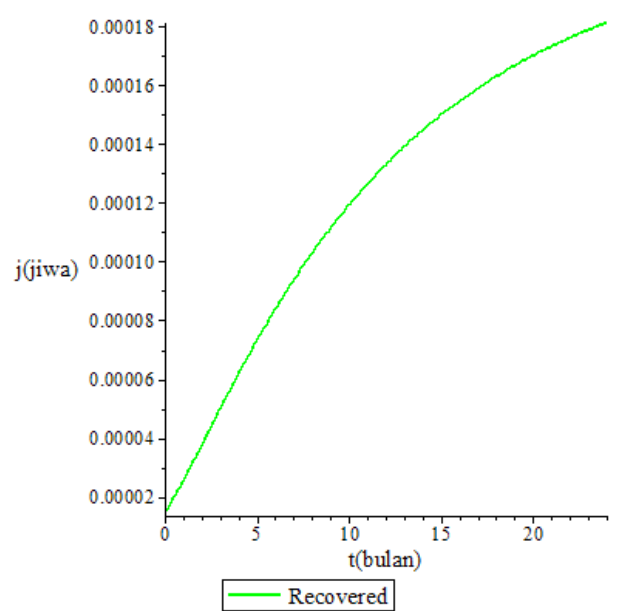

(d)

GAMBAR 3. (c) Simulasi untuk populasi infected

(d) Simulasi untuk populasi recovered

Gambar 3(c) dapat dilihat bahwa populasi individu yang terinfeksi (infected) mengalami peningkatan secara drastis dari bulan ke-0 hingga bulan ke-11 dengan jumlah populasi 300 jiwa. selanjutnya populasi mengalami titik konstan setiap bulannya.

Gambar 3(d) dapat dilihat bahwa populasi individu yang sembuh (recovered) mengalami peningkatan secara drastis dari bulan ke-0 hingga bulan ke-24 yaitu dari titik awal 88 menuju 1587 jiwa.

Simulasi untuk $\varepsilon=0,9$ dimana parameter $\varepsilon$ adalah laju kesembuhan tiap individu yang terinfeksi karena adanya pengobatan.

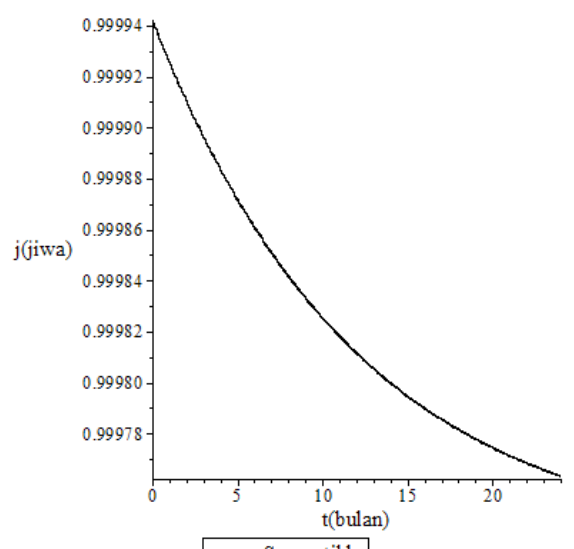

(a)

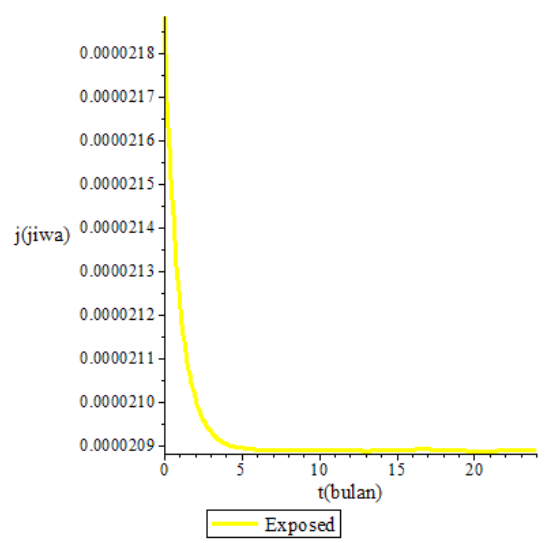

(b)

GAMBAR 4. (a) Simulasi untuk populasi susceptible

(b) Simulasi untuk populasi exposed 
Gambar 4(a) dapat dilihat bahwa populasi individu rentan (susceptible) mengalami penurunan di titik awal 8.818.970 jiwa pada bulan ke-0 dan menghilang pada bulan ke-24.

Gambar 4(b) dapat dilihat bahwa populasi individu yang menunjukkan gejala (exposed) mengalami penurunan dari titik awal 193 jiwa di bulan ke-0 hingga menghilang pada bulan ke22.

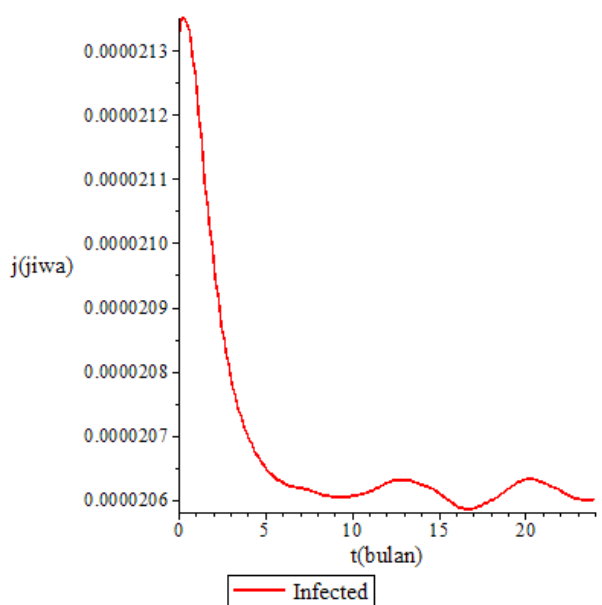

(a)

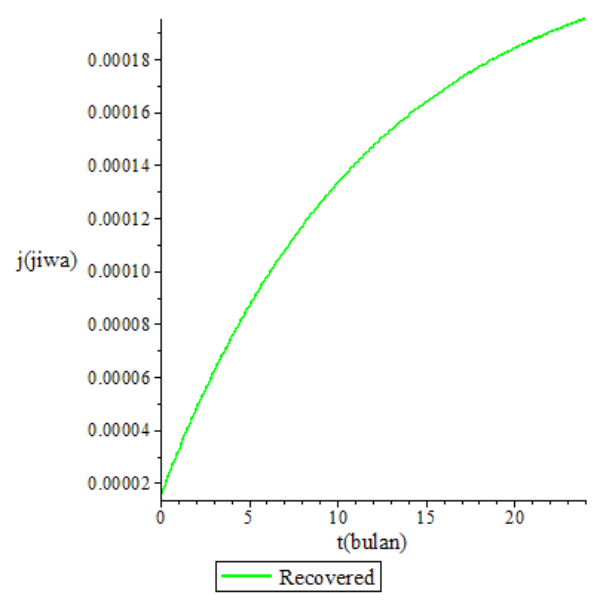

(b)

GAMBAR 4. (c) Simulasi untuk populasi infected

(d) Simulasi untuk populasi recovered

Gambar 4(c) dapat dilihat bahwa populasi individu yang terinfeksi (infected) mengalami penurunan secara drastis dari bulan ke-0 hingga bulan ke-9 jengan jumlah populasi 181 jiwa. selanjutnya populasi mengalami naik turun hingga bulan ke-24.

Gambar 4(d) dapat dilihat bahwa populasi individu yang sembuh (recovered) mengalami peningkatan secara drastis dari bulan ke-0 hingga bulan ke-24 yaitu dari titik awal 88 menuju 1676 jiwa.

\section{PEMBAHASAN}

Hasil simulasi menggunakan data penderita kanker kulit yang diperoleh dari Rumah Sakit Wahidin Sudirohusodo di kota Makassar pada tahun 2018 hingga tahun 2019, diperoleh bahwa semakin besar persentase laju kesembuhan tiap individu yang terinfeksi karena adanya pengobatan mengakibatkan populasi pada kelas recovered semakin meningkat dan populasi pada kelas infected mengalami penurunan. Analisis kestabilan bilangan reproduksi dasar $\left(R_{0}\right)$ model SEIR pada kanker kulit diperoleh nilai nilai $R_{0}$ sebanyak tiga yaitu sebesar 0.001327855279, 0.004230271191 , dan 0.007132687102 . Dari ketiga nilai $\left(R_{0}\right)$ tersebut lebih kecil dari 1 berarti seseorang yang terinfeksi kanker kulit tidak menyebabkan orang lain terkena penyakit yang sama. Dengan kata lain penyakit kanker kulit tidak mewabah di Provinsi Sulawesi Selatan.

\section{KESIMPULAN}

Analisis kestabilan bilangan reproduksi dasar $\left(R_{0}\right)$ model SEIR pada kanker kulit akibat paparan sinar ultraviolet di Provinsi Sulawesi Selatan diperoleh nilai nilai $R_{0}$ sebanyak tiga yaitu sebesar $0.001327855279,0.004230271191$, dan 0.007132687102 . 
Hasil simulasi model SEIR pada kanker kulit menggunakan data penderita kanker kulit yang diperoleh dari Rumah Sakit Wahidin Sudirohusodo di kota Makassar pada tahun 2018 hingga tahun 2019, diperoleh bahwa semakin besar persentase laju kesembuhan tiap individu yang terinfeksi karena adanya pengobatan mengakibatkan populasi pada kelas recovered semakin meningkat dan populasi pada kelas infected mengalami penurunan. Dengan kata lain penyakit kanker kulit tidak mewabah di Provinsi Sulawesi Selatan.

\section{DAFTAR PUSTAKA}

Campbell, S. L., \& Haberman, R. (2008). Introduction to Differential Equations with Dynamical System. New Jersey: Princeton University Press.

Edwards, C. H., \& Penney, D. E. (2001). Differential Equation and Linear Algebra. New Jersey : Prentice hall Inc.

Fadillah, D. (2017). Insiden Penyakit Kanker di RSUP Dr. Wahidin Sudirohusodo Makassar Periode Januari 2015 - Juni 2017 (Skripsi). Universitas Hasanuddin, Makassar.

Hanisar. (2016). Pemodelan Matematika Tipe SEIR pada Populasi Perokok (Skripsi). Universitas Halu Oleo, Kendari.

Hariyanto. (1992). Persamaan Diferensial Biasa Modul 1-9. Jakarta: Universitas Terbuka.

Hendaria, M. P., Asmarajaya, AAGN., \& Maliawan,S. (2013). Kanker Kulit. E- Jurnal Medika Udayana, 2(2). 273 -289.

Iswanto, R. J. (2012). Pemodelan Matematika: Aplikasi dan Terapannya. Yogyakarta : Graha Ilmu.

Kim S. Y., \& Yun S. J. 2016. Cutaneous Melanoma in Asians. Chonnam Med J, 52(3). 185-193

Robinson, R. C. (2004). An Introduction To Dynamical Systems Continuous and Discrete. New Jersey : Pearson Education Inc.

Rosidah, S., Sardjono, Y., \& Sumardi, Y. (2017). Analisis Dosis BNCT Pada Kanker Kulit Melanoma Menggunakan MCNPX dengan Sumber Neutron dari Kolom Termal Reaktor Kartini. Jurnal Fisika, 6(5). 352 - 359.

Ross, S. L. (1984). Differential Equation. New York: John Willey and Sons Inc.

Side, S. (2015). Model SEIR pada Penularan Hepatitis B. Jurnal Scientific Pinisi, 1(1). 97-102.

Side, S., \& Rangkuti, Y. M. (2015). Pemodelan Matematika dan Solusi Numerik untuk Penularan Demam Berdarah. Medan: Perdana Publishing.

Svobodova, A., Walterova, D., \& Vostalova, J. (2006). Ultraviolet Light Induced Alteration to The Skin. Biomed Pap Med Fac Univ Palacky Olomouc Czech Repub, 150(1). 25-38.

Wilvestra, S., Lestari, S., \& Asri, E. 2018. Studi Retrospektif Kanker Kulit di Poliklinik Ilmu Kesehatan Kulit dan Kelamin RS Dr. M. Djamil Padang Periode Tahun 2015 - 2017. Jurnal Kesehatan Andalas, 7(3). 47 - 49. 